IFN Working Paper No. 729, 2008

\title{
How Wage Compression Affects Job Turnover
}

Fredrik Heyman 


\title{
How Wage Compression Affects Job Turnover
}

\author{
Fredrik Heyman*
}

Forthcoming in Journal of Labor Research

\begin{abstract}
I use Swedish establishment-level panel data to test Bertola and Rogerson's (1997) hypothesis of a positive relation between the degree of wage compression and job reallocation. Results indicate that the effect of wage compression on job turnover is positive and significant in the manufacturing sector. The wage compression effect is stronger on job destruction than on job creation, consistent with downward wage rigidity. Further results include a strong positive relationship between the fraction of temporary employees and job turnover and a negative relationship between the amount of working-time flexibility and job reallocation.
\end{abstract}

Keywords: Job creation and job destruction, wage dispersion, temporary employment contracts, panel data.

JEL: $\quad$ J21, J31, J63.

\footnotetext{
* This is a revised version of FIEF Working Paper, No. 193, 2004. I am grateful for comments from Mahmood Arai, Erling Barth, John Earle, Mikael Lindahl, Lena Nekby, Mårten Palme, Jonas Vlachos, an anonymous referee, and seminar participants at FIEF, Stockholm School of Economics, Swedish Institute for Social Research, Stockholm University and at the European Economic Association meeting in Lausanne. I also thank the National Institute of Economic Research (NIER) for providing me with data. Research Institute of Industrial Economics, P.O. Box 55665, SE-102 15 Stockholm, Sweden, e-mail: fredrik.heyman@ifn.se.
} 


\section{Introduction}

In the past decade, the rate of gross job turnover in different markets has been estimated in numerous empirical studies. ${ }^{1}$ Studies based on US and European data yield very similar results: The job reallocation rate (job creation + job destruction) is approximately 20 percent in the observed countries. Given the large institutional differences in terms of job security legislation and unionization, the similarity between Europe and the US may seem surprising. ${ }^{2}$

One possible explanation for similar labor reallocation rates across labor markets with very different employment-protection legislations concerns differences in wage-setting institutions. Bertola and Rogerson (1997) argue that although jobsecurity laws reduce job flows, their effect might be diluted if other institutional differences have opposite effects. One such difference is wage setting. Wage-setting institutions are, in general, much more centralized in Europe than in the US which, in turn, leads to greater uniformity of wages across industries and firms. A compressed wage structure implies that firms cannot adjust wages in response to positive or negative demand shocks. Instead, either the number of employees or the number of hours worked by the workforce must be adjusted. This implies, all else equal, a positive relationship exists between the degree of wage compression and the magnitude of gross job flows. ${ }^{3}$

Bertola and Rogerson's conclusion is that when labor-protection laws and wage-setting institutions are considered jointly, the result might be that job flows in countries with high adjustment costs and a compressed wage structure mimic those in

\footnotetext{
${ }^{1}$ See Leonard (1987), Dunne et al. (1989) and Davis and Haltiwanger $(1992,1997,1999)$ for job flows. Anderson and Meyer (1994), Lane et al. (1996), Hamermesh et al. (1996), Albeack and Sörensen (1998) and Abowd et al. (1999) study both job- and worker flows. Three Swedish studies are Persson (1999), Andersson (1999) and Arai and Heyman (2004).

${ }^{2}$ An exception is Blanchard and Portugal (2001), who in a comparative study on Portugal and the US, find that annual job flows are similar across the two countries, but quarterly flows are considerable higher in the US than in Portugal. Their explanation of this is that differences in employment legislation give rise to different movements in the transitory and permanent components of employment dynamics. See also Addison and Teixeira (2003) for an extensive discussion on the effects of employment protection on job flows.

${ }^{3}$ A similar relationship can be found in Moene and Wallerstein (1997). They investigate the effects on growth of wage compression through centralized bargaining. Bertola and Ichino (1995) also analyze this relationship and argue that compressed wages contribute to higher worker mobility.
} 
countries with low adjustment costs and decentralized wages. If wage-setting institutions have a significant effect on the reallocation of jobs, this may partly explain the reported similarities between European and US job reallocation rates.

Evidence presented in OECD (1993, 1996) and Blau and Kahn (1996) is consistent with the notion that European wages are more compressed than US wages. Moreover, wage-setting institutions and the degree of wage compression may be an important factor behind observed similarities between European and US gross job flows.

Despite the attention that Bertola and Rogerson's article has received in explaining similarities between European and US job flows, their model has not been empirically tested. My purpose herein is to empirically test the Bertola and Rogerson hypothesis of a positive relationship between the degree of wage compression and job turnover on Swedish panel data. The Bertola and Rogerson model is extended by taking into account that total labor input is a function of both the number of employees and the hours worked. This extension takes into consideration that in response to a negative shock, firms can choose between reducing the number of employees and paying the relevant adjustment costs or adjusting the hours worked by existing employees.

Although the Bertola and Rogerson model is constructed to explain differences between economies, I use Swedish data to analyze the relationship between wage compression and job reallocation at the industry level, i.e., explore industry variation within Sweden. The advantage of this approach, compared to a comparative study between different countries, is that controlling for differences that may affect job reallocation rates, in addition to the wage distribution, is more manageable between industries, or over time, in the same country rather than between economies. ${ }^{4}$ The data contain quarterly information on establishment employment turnover and wages for a panel of more than 10,000 establishments in the Swedish private sector, covering the time period 1992:3 to 1999:2.

\footnotetext{
${ }^{4}$ Moreover, due to data quality considerations such as country differences in sample coverage, definitions of establishments, the ability to link establishments over time and sector coverage, crosscountry comparisons on gross job flows and wage dispersion are problematic. These problems are discussed in Davis and Haltiwanger (1999) and Addison and Teixeira (2003).
} 
The results suggest substantial sector heterogeneity. In the preferred model, industry heterogeneity is controlled for by using fixed effects. The effect of wage dispersion on job turnover is negative and significant in the manufacturing sector. This supports the Bertola and Rogerson hypothesis that a more compressed wage structure will result in higher job reallocation rates. Estimating separate models for job creation and destruction show a negative and significant effect of wage dispersion on job destruction, whereas the effect is insignificant in the job creation-equation. These results are consistent with wages being more rigid downwards than upwards. No support for the Bertola and Rogerson model is found in the non-manufacturing sector.

The share of temporary employees is used as a proxy for adjustment costs. Firms with a high fraction can more easily adapt to changes in demand by adjusting its stock of temporary employees, since the hiring and firing costs are lower for temporary than for permanent contracts. This means that firms in industries with a high fraction of temporary workers can use temporary contracts as a buffer for shifts in labor demand, to a higher degree than firms with a low fraction of temporary employees. Consequently, costs for adjusting the labor force become lower for firms with a high fraction of temporary employees than for those with a low fraction of such worker. The results show a strong positive relationship between the industry-share of temporary employees and job turnover.

The remainder of the paper is organized as follows: Section II gives a brief description of the Swedish labor legislation and the wage-setting system. Data are presented in Section III. The empirical specification is given in Section IV. Section V reports estimation results and discusses their implications for the observed stylized fact that European and US gross job flows are of the same magnitude. Finally, section VI concludes.

\section{Labor Market Legislation and Wage Formation in Sweden}

Labor Market Legislation. The Swedish Employment Protection Act (LAS) has traditionally been built on two principles: permanent contracts for an indefinite period of time as the normal type of employment and dismissals based on just-cause 
only. The legislation also contains rules on notification periods and priority rules for layoffs. In the last two decades, however, a gradual liberalization of the labor laws has occurred. For instance, in 1982 the use of fixed-term contracts was relaxed with the introduction of a trial period. Strict priority rules such as last in, first out, have also been relaxed.

The Swedish labor legislation is much more restrictive for permanent than for temporary contracts. In order to restrict the use of temporary contracts, LAS lists cases in which fixed-term contracts are allowed. ${ }^{5}$ The most important cases where timelimited contracts are permitted are (i) one trial period of six months, (ii) seasonal or temporarily excessive workloads, (iii) replacement of employees on leave, and (iv) a few other cases. In some cases, there are limitations to the duration of the contract. Employees are, for example, obliged to transform a temporary contract into a permanent one if the employee has had time-limited contracts for 3 years in a 5-year period.

In 1997, the rules concerning fixed-term contracts were relaxed in so far that these could be made without specifying an objective reason, under the condition that no more than five workers were employed on a fixed-term basis at the same time. Furthermore, the maximum duration of temporary contracts was extended to 18 months for newly established firms.

Given that the Employment Protection Act covers the whole labor market, there are no legal differences in the use of temporary contracts between, e.g., manufacturing and services. Furthermore, according to Holmlund and Storrie (2002), the regulation of fixed contracts in collective agreements has not altered the regulations in LAS. Hence, the possibilities to use flexible fixed-term contracts according to the law and collective agreements are not significantly different between manufacturing and services.

Regarding the termination costs of employment contracts, LAS is more restrictive for permanent than for temporary contracts. Under these circumstances, a firm that increases employment is likely to initially increase the number of temporary workers to obtain an option to transform some of temporary contracts into permanent

\footnotetext{
${ }^{5}$ Additional possibilities for fixed-term contracts may be created in collective agreements between employers' and employees' organizations.
} 
ones if there is a decrease in the initial uncertainty about demands. Analogously, in a downturn, temporary contracts are the first to be terminated. The lower termination costs associated with temporary contracts enable firms to reduce adjustment costs by using temporary workers as a buffer for employment adjustment, so temporary contracts are more volatile than permanent contracts. ${ }^{6}$

The option of using flexible workers in the production process differs among firms in different industries. For instance, technological and organizational differences between manufacturing and non-manufacturing establishments could imply different possibilities of utilizing temporary employment. Table A1 in the Appendix displays a large variation among sectors in the fraction of temporary workers. Service industries like Trade, Real estate and Other services have the highest fraction, whereas the lowest fraction is in traditional manufacturing industries such as Machinery, Electricity, and Textiles.

Wage Formation. Beginning in the 1950s, for several decades Swedish wage formation was heavily influenced by the principle of a solidarity wage policy which emphasized "equal pay for equal work" as one of the cornerstones of the so-called Swedish model. From an industrial policy perspective, the idea behind "equal pay for equal work" was to set pressure on weak firms, and gradually force them out of the market, thereby enhancing industry productivity. Active labor market policy allocated labor from declining to expanding industries and regions. A solidaristic wage policy was also made possible by a highly centralized wage bargaining system.

During the period 1956 - 83, centrally negotiated wage agreements were made by the two main parties on the Swedish labor market: the Swedish Trade Union Confederation (LO) and the Swedish Employers' Confederation (SAF). These framework wage agreements were then followed by negotiations at both the industry and local levels. Centrally negotiated wage levels were more or less binding and often included special low-wage provisions to increase the relative wage of workers at the lower end of the wage distribution. As a result of the egalitarian wage policy, wage

\footnotetext{
${ }^{6}$ See Bentolila and Saint-Paul (1992), Saint-Paul (1996), Wasmer (1999), Goux et al. (2001), Blanchard and Landier (2002) and Holmlund and Storrie (2002) for analyses of temporary and permanent employment.
} 
dispersion in Sweden, measured as the total variance of blue-collar workers, declined by 75 percent between 1962 and 1983 (Hibbs and Locking, 2000). Hibbs and Locking (2000) noted that the Swedish wage distribution was so compressed that a relative wage increase of around 30 percent would take a worker from the $10^{\text {th }}$ to the $90^{\text {th }}$ decile of the wage distribution.

The decline in wage inequality ended in the 1980s as a result of the breakdown of centrally negotiated wage agreements between LO and SAF. Wage agreements after 1983 have primarily involved industry-level negotiations so Sweden has gone from a tri-level bargaining system to a two-level system with industry- and plant-level bargaining. Furthermore, the egalitarian view of wage setting faded and practically disappeared around 1990. The effect of these changes in the wage-formation process on relative wages was quite dramatic: Between 1983 and 1993, the relative wage dispersion increased by approximately 50 percent (Edin and Holmlund, 1992; Hibbs and Locking, 2000) so the wage dispersion in the early 1990s was about the same as that in the mid-1970s. The trend towards increased wage inequality continued in the 1990s, hand in hand with a more decentralized wage bargaining system. However, from an international perspective, the Swedish wage distribution is still very compressed. The gradual shift towards a greater local element in the wage formation came about in both the manufacturing and the service sectors.

However, at the end of the 1990s, the degree of coordination increased in the manufacturing sector when a new form of informal coordination was introduced in 1997. An agreement on industrial development and wage formation was signed, determining rules for industry-level bargaining within 60 bargaining units in the manufacturing industry. Similar agreements have also been signed between whitecollar workers and employers in retail trade in the Service sector. Table A1 in Appendix shows that for the period 1992-1999, wage dispersion is higher in service than in manufacturing, particularly for white-collar workers. 


\section{Data and Descriptive Statistics}

The data are taken from Short Term Wage Statistics (Konjunkturstatistik, löner för privat sektor) and Short Term Employment Statistics (Kortperiodisk Sysselsättningsstatistik) collected by Statistics Sweden (SCB). Each data set contains information on employment turnover and wages for a panel of more than 10,000 establishments in the non agricultural private sector. Detailed 5-digit industry SICcodes allow the data to be matched at different industry levels.

The Short Term Wage Statistics collects information on wages for blue- and white-collar workers quarterly for the period 1991-1995 and monthly from $1996 .{ }^{7}$ A representative sample is drawn from the population of private sector establishments with at least five employees, stratified according to industry affiliation and employment size. The sample covers establishments/plants in machinery and mining (SIC codes $\mathrm{C}+\mathrm{D}$ ) and firms in the service sectors. For blue-collar workers, the survey asks questions about number of hours worked, number of overtime hours worked, average hourly earnings excluding and including retroactive wage supplements and number of blue-collar employees. For white-collar workers the variables are negotiated monthly salary excluding and including commissions and retroactive wage supplements and number of white-collar employees. Five-digit SIC codes are available for all firms and establishments.

Real wages were more or less unchanged during the period 1992-1995, but have thereafter increased mostly due to the low inflation in this time period. During this period, inflation decreased from above 10 percent in 1991 to around zero in 1999. The annual mean real wage increase for the entire period is 2.2 percent for blue-collar workers and 2.7 percent for white-collar workers. Table A1 in the Appendix shows descriptive statistics for 14 industries (6 in manufacturing and 8 in non-manufacturing) and displays inter-industry wage differentials. For blue-collar workers, the highest wages are found in Mining and Wood, whereas the lowest wages are in Hotel and Banking. White-collar workers receive the highest wages in Banking and Chemistry and the lowest in Transport and Hotel.

\footnotetext{
${ }^{7}$ The two groups of workers are defined according to their union affiliation.
} 
The coefficient of variation, $C V(=s t d(W) /$ mean $(W))$, is used as a measure of total and industry wage dispersion. Each group is weighted by its share of the total wage sum. When computing industry variation in wages I use the share of wages for white- and blue-collar workers for each industry and time period, $V_{i t W}$ and $V_{i t B}$, respectively. Hence, the following measures for variation in wages for industry $i$ at time $t$ will be used:

(1) $C V_{i t}=V_{i t B} \frac{\operatorname{std}\left(W_{i t B}\right)}{\operatorname{mean}\left(W_{i t B}\right)}+V_{i t W} \frac{\operatorname{std}\left(W_{i t W}\right)}{\operatorname{mean}\left(W_{i t W}\right)}$,

where $t=1992: 3, \ldots, 1999: 2$ and $i=1, \ldots 14$. The mean coefficient of variation for the whole period is 0.14 for blue-collar workers and 0.17 for white-collar workers.

An often used measure for wage dispersion is the 90-10th percentile ratio. To check for robustness of the results, I also estimate equations using this ratio instead of the coefficient of variation. Industry means are presented in Table A1 in the Appendix.

The Short Term Employment Statistics contain quarterly information on the stock of permanent and temporary contracts as well as direct information on hires and separations for permanent and temporary workers. The data are obtained from a random sample from the population of private-sector establishments of all sizes in Sweden, stratified according to industry affiliation and establishment size. The establishments are randomly divided into three equal groups. Every quarter, each group responds to questions on employment and worker turnover for one particular month in the quarter each. The information on the number of employees refers to a particular date in the month, while separations and hires refer to flows during the entire month. As an example, one third of the sampled establishments in the second quarter reports information for April, while the other two groups report the corresponding information for May and June. The information on establishment employment as well as hires and separations is supplied for both permanent (time unlimited) and temporary (time limited) contracts, separately for men and for women. Arai and Heyman (2004) provide more details on the data. 
Job flows are computed on the basis of the changes in the number of employees $(n)$ at establishment $(e)$ over time $(t){ }^{8}$ Job Creation $(J C R)$ and Job Destruction (JDR) rates for industry $i$ at time $t$ are given by:

(2) $\quad J C(D)_{i t}=\frac{\sum_{e}\left(\mid n_{e t}-n_{e, t-1}\right)}{\sum_{e} 0.5\left(n_{e t}+n_{e, t-1}\right)} ; \quad$ if $n_{e t} \geq(\leq) n_{e, t-1}$.

Net employment growth is equal to the difference between JCR and JDR whereas job reallocation is equal to the sum of $J C R$ and $J D R$. Table A2 presents mean quarterly gross job flow rates for the period 1992-1999.

Job creation is, on average, 4 percent and varies between 2 and 6 percent. The corresponding figure for job destruction is 5 percent, varying between 3 and 6 percent. The mean job reallocation rate is 9 percent. Gross job flows are higher in nonmanufacturing than in manufacturing for individual industries among 14 two-digit industries, the highest job reallocation rates are observed in Hotel, Construction and Real estate. The lowest job reallocation rates are in Textiles, Chemistry and Metal and manufacturing.

\section{Empirical Specification}

The theoretical model on the relationship among wage compression, adjustment costs, and job turnover gives several qualitative predictions. ${ }^{9}$ First, job reallocation is increasing in the degree of wage compression and decreasing in the amount of hours worked and overtime. A more frequent use of overtime in expansions will lead to less new hire and less labor turnover. ${ }^{10}$ Finally, the level of job reallocation is negatively related to the cost of hiring and firing.

\footnotetext{
${ }^{8}$ In order to be compatible to the wage data, job flows are calculated for establishments with at least five employees.

${ }^{9}$ See Bertola and Rogerson (1997) for the original theoretical model and Heyman (2002) for details on extensions of the model.

${ }^{10}$ In Europe, the scope for substituting hours for workers is in reality asymmetric. Employers cannot decrease the number of hours worked for the workforce, and thereby save on the wage per employee. In many European countries the extent to which overtime is used is determined through negotiations between employer organizations and unions or through legislation.
} 
I use the coefficient of variation to measure wage dispersion and the fraction of temporary employment to proxy labor adjustment costs which are higher for permanent contracts than for temporary ones. Given that the employment legislation concerning permanent and temporary contracts is identical in all industries, I make the plausible assumption that the possibilities to use temporary workers are exogenous and driven by technological and organizational differences across firms and industries. This means that firms in industries with a high fraction of temporary workers can use temporary contracts as a buffer for shifts in labor demand to a higher degree than firms with a low fraction of temporary employees. Consequently, adjustment costs become lower for firms with a high fraction of temporary employees than for those with a low fraction of such workers.

The following specification is used to test the predictions from the theoretical model empirically:

(3) $J R R_{i t}=\beta_{0}+\beta_{1}$ WDISP $_{i t}+\beta_{2}$ TEMP $_{i t}+\beta_{3} O V E R T_{i t}+\beta_{4} N E T_{i t}+v_{i}+\varepsilon_{i t}$

where $J R R_{i t}$ is job reallocation in industry $i$ at time $t$; WDISP is wage dispersion; TEMP is the fraction of temporary employees in relation to total employment; and OVERT is the fraction of overtime hours in relation to the total number of hours worked. All equations include NET, net employment change, reflecting the current state of the business cycle. $v_{i}$ is a time-invariant industry-specific effect, and $e_{i t}$ is the usual error term.

All variables are industry-sector means (6 manufacturing and 8 nonmanufacturing industries), roughly corresponding to the two-digit system of industry classification. $^{11}$

Since downward wage rigidity is likely to be more common, wage dispersion should have a larger effect on job destruction than on job creation. ${ }^{12}$ The question of

\footnotetext{
${ }^{11}$ In 1993, the Swedish industry classification changed systems from SNI69 to SNI92. The 14 industries analyzed in this paper are constructed so as to enable comparisons over time. To check for robustness to industry classification, all equations are re-estimated using the new industry classification. This corresponds to data for 47 industries in the period 1993 to 1999. With a few exceptions, the results remain unchanged.
} 
asymmetric effects on job creation and job destruction is not addressed in the theoretical model. Still, given that total job reallocation consists of both job creation and destruction, it is highly relevant to investigate the issue. Therefore, I will also estimate equation (3) with job creation and job destruction separately as dependent variables.

The fixed-effect model assumes the industry-specific effect, $v_{i}$, is non stochastic. The random-effect model assumes that the industry-specific error term is random and drawn from a common distribution independent of the explanatory variables. A priori, it is not obvious which model should be used. The Hausman test is used to discriminate between the fixed- and the random-effect models (Baltagi, 1995). This is a test for correlation between the industry-specific effects and the independent variables.

A potential econometric problem to consider is the endogeneity of the wage dispersion variable which could arise if, for instance, firm and industry characteristics in industries with high job flows influence the wage distribution. Industry-differences in e.g., market structure, union power, and the possibilities to use temporary employees as well as technological and organizational differences may affect both job flows and the distribution of wages systematically. To deal with the possibility of endogeneity in the wage dispersion variable, IV-estimations and Wu-Hausman tests for endogeneity are presented. ${ }^{13}$ Lagged values of wage dispersion is used as an instrument for wage dispersion.

I also apply IV-analysis to investigate the issue of endogeneity of fraction of temporary employees and use of overtime. Again, lagged values are used as instruments.

\footnotetext{
${ }^{12}$ Recently, several papers have used survey data consisting of interviews with managers and labor representatives to explore the mechanism behind nominal wage rigidity and why nominal wages are so insensitive to macroeconomic shocks (see e.g. Agell and Lundborg (2003) and Bewley (1998)). In the Agell and Lundborg (2003) study, covering firms in the Swedish manufacturing sector, only 2 firms out of 153 had experienced nominal wage cuts during the 1990s. The low figure is despite the largest economic downturn in Sweden since the 1930s.

${ }^{13}$ The Wu-Hausman test tests if there is a significant difference between the OLS- and the IV-estimator. Both estimators are consistent in the case of no correlation between the regressors and the errors. However, only the OLS-estimator is efficient. If the null hypothesis is false, only the IV-estimator is consistent.
} 


\section{Results}

Results are presented in Tables 1-3. Table 1 shows the empirical results on equation (3) for the entire private sector, as well as for the manufacturing and service sectors separately. Furthermore, estimations are also presented using the 90-10th percentile ratio as an alternative measure of wage dispersion. Table 2 shows empirical results when job creation and job destruction are used separately as dependent variables. Results from IV-estimations are presented in Table 3.

The Hausman tests presented in Tables 1 and 2 and in unreported estimated equations show that the random-effects estimator can be rejected. The positive correlation between the regressors and the individual-specific effects means that there are unobservable effects that differ between industries. By performing the fixedeffects technique, the $v_{i}$ 's are wiped out, leaving the within-estimator unbiased and consistent for $\beta$.

Considering the results for job reallocation, for the entire private sector (column 1), WDISP is not significant. The other variables all have expected signs and are significantly different from zero. The positive sign for TEMP indicates a higher job turnover in firms in industries with a high fraction of temporary employees so these firms can more easily adapt to changes in labor demand by changing the number of temporary employees.

The coefficient for the overtime variable, OVERT, is negative, suggesting that job turnover is lower in industries where the number of working hours is relatively flexible. Rather than changing the number of employees, firms can adjust the number of hours worked per employee.

The descriptive statistics presented in Tables A1 and A2 indicate large differences between industries in manufacturing and non-manufacturing. Therefore, differences between the two sectors may influence the estimated coefficients. An insignificant effect of wage dispersion on job turnover at the aggregate level might mask important sector heterogeneity.

To check for sector heterogeneity, separate regressions are estimated for manufacturing and non-manufacturing, respectively, as reported in columns 2 and 3. 
The effect of wage dispersion on job turnover is negative and significant in manufacturing. The estimate of WDISP suggests that in the manufacturing sector, a more compressed wage structure leads to a higher job reallocation rate, in accordance with the Bertola and Rogerson hypothesis. The point-estimate is -0.33 , implying that a one standard deviation increase in WDISP reduces $J R R$ by 0.007 , which amounts to 12 percent of the median of $J R R$. The corresponding effect is 14 percent for an industry in the 10th percentile of the job reallocation distribution.

Interaction terms between the wage dispersion variable and the share of temporary employees, overtime, and net employment change, are never significant. Hence, I find no evidence that the effect of wage dispersion differs systematically between firms with different fractions of temporary employees or a different use of overtime. Furthermore, results are unchanged when I add a time dummy for periods when rules for fixed-term contracts were relaxed.

Turning to the non-manufacturing sector, the effect of wage dispersion is reversed. Column 3 displays a positive and significant correlation between WDISP and $J R R$ in the service sector.

Hence, sector differences seem to play an important role in determining the relationship between the degree of wage compression and job reallocation. Note that the rate of job reallocation differs across sectors of activity. Job flows are much lower in manufacturing than in non-manufacturing. The quarterly job reallocation rate is on average 6 percent in manufacturing as compared to 10 percent in non-manufacturing. Examining these flows in 14 industries, job reallocation turns out to be largest in hotels and restaurants, construction, services and trade. The lowest job reallocation rates are observed in food, mining, metal and machinery. Furthermore, technological and organizational differences between, on average, larger capital-intensive firms in manufacturing and smaller firms in the service sector may affect the extent to which jobs are reallocated. Reallocation in large capital-intensive manufacturing establishments is characterised by high costs. On the contrary, smaller and less capital intensive service-oriented establishments might easier adjust to changes. Previously, both Boeri (1999) and Arai and Heyman (2004) have found differences in the cyclical pattern for job reallocation between the manufacturing and service sectors. For 
instance, Arai and Heyman only find a countercyclical pattern for permanent contracts in the manufacturing sector. No cyclical pattern is found in non-manufacturing. Their conclusion is that industries that can adjust employment by using temporary workers are characterized by smooth job reallocation and thus do not exhibit any cyclical pattern in job reallocation. The observed counter-cyclical job reallocation in manufacturing might reflect this sector's limited possibilities of using temporary contracts as an adjustment buffer which leads to sluggish labor adjustment. This could also have an impact on how job turnover is affected by changes in the wage distribution.

The coefficients for the fraction of temporary employees and overtime have expected signs and are significant in both sectors. Net employment change is negative and significant in manufacturing, thereby reflecting a countercyclical pattern in job reallocation. This is not the case in the non-manufacturing sector where the coefficient for employment growth is insignificant. This result is in line with Boeri (1996) and aria and Heyman (2004), stressing that countercyclical job turnover mainly concerns the manufacturing industry.

An often used measure for wage dispersion is the 90-10th percentile ratio. To check for robustness of the results, I also estimate equations using this ratio instead of the coefficient of variation. Results are displayed in columns 4-6 in Table 1.

Results for the wage dispersion variable remain qualitatively unchanged. The effect of wage dispersion on job turnover is negative in manufacturing, whereas it is positive in non-manufacturing. The estimated coefficient is equal to -0.09 in the manufacturing sector, so an increase in wage dispersion of one standard deviation reduces job reallocation by 0.005 . Given that the median job reallocation rate is equal to 0.056 , the estimate indicates that a one standard deviation increase in wage dispersion reduces total job turnover in the median industry by approximately 9 percent.

According to Blanchard and Portugal (2001), the lower the frequency at which one study employment changes, the more important will be the permanent component relative to the transitory component. The data used in this study restricts the possibility to evaluate yearly changes since data only cover seven years. This means 
that it is not possible to compare results from different frequencies, as is done in Blanchard and Portugal. I have, however, experimented with estimations of models that are separated by type of employment contract (temporary and permanent) to evaluate the relative importance of the permanent and temporary components, respectively. The presence of fixed-term contracts with low adjustment costs makes employment more responsive to shocks in labor demand, and hence more volatile. However, volatile temporary employment contracts can coexist with more stable employment for employees with permanent contracts. This can possibly lead to a segmented labor market with one group of workers with unstable employment that acts as a buffer for changes in demand for labor.

Results from the contract-specific regressions are mixed. There is, however, a tendency for a significantly higher responsiveness of temporary contracts then of permanent ones. The negative effect of wage dispersion on job reallocation (in line with the Bertola and Rogerson hypothesis) seems to originate from a very strong effect associated with employment changes among temporary employees. ${ }^{14}$

Table 2 displays results when job creation and job destruction are used separately as dependent variables. The wage dispersion variable is not significant, neither in the full sample nor in the non-manufacturing sector. In manufacturing, WDISP is negative for both job creation and job destruction, having a higher coefficient value (in absolute terms) for job destruction. However, the variable is only significant for job destruction.

For the manufacturing sector, results are in accordance with wages being more downward than upward rigid, thereby leading to higher rates of job turnover in economic downturns than in economic upturns. Hence, asymmetric wage rigidity, in that wages are more rigid downward than upward, seems to influence how the wage distribution affects job turnover. More specifically, the combination of a compressed wage structure, more downwardly rigid wages, and a deep recession in the Swedish manufacturing sector in the early 1990s may explain the observed sector differences regarding the relationship between the wage structure and the reallocation of jobs. The sector differences support the Bertola and Rogerson hypothesis of a negative

\footnotetext{
${ }^{14}$ Results can be obtained from the author upon request.
} 
relationship only in the manufacturing sector. However, the economic significance is rather small; only a small fraction of the variation in job turnover is explained by the degree of wage compression.

Finally, to exploit the question of endogeneity in wage dispersion, instrumental variable regressions are estimated together with $\mathrm{Wu}-H a u s m a n$ tests for endogeneity. Table 3 displays the results for the manufacturing sector.

In all equations, one year lags of WDISP are used as instrument for WDISP. ${ }^{15}$ As can be seen from Table 3, IV-estimation does not change the results for wage dispersion. The wage dispersion variable is negative and significant in both the equation with total job reallocation as the dependent variable (column 1), and the equation with job destruction as the dependent variable (column 3). The other explanatory variables remain qualitatively unchanged. The similar results obtained from OLS and IV are confirmed by the Wu-Hausman tests and results show that there is no significant difference between the OLS-estimator and the IV-estimator. This suggests that exogeneity of WDISP cannot be rejected, and we can rely on results obtained in the industry fixed-effects models discussed above.

The same also applies to endogeneity of fraction of temporary employees and use of overtime. Unreported results show that exogeneity of these variables cannot be rejected. According to the Wu-Hausman tests, no significant differences between the OLS- and IV-estimators are found when lagged values of the respective variable are used as instruments. ${ }^{16}$

\footnotetext{
${ }^{15}$ Results are robust to time-structure choice.

16 These unreported results can be obtained from the author upon request.
} 


\section{Summary and Conclusions}

One puzzle from the job creation and job destruction literature is the similar pattern of flows observed in both the US and Europe. Given that the European labor market is more regulated than the US, we would expect significantly higher job flows in the US than in Europe. Bertola and Rogerson propose one explanation for the observed similarities and argue that differences in wage-setting institutions play an important role and that there is a positive relationship between the degree of wage compression and gross job flows. This means that job flows in countries with high adjustment costs and a compressed wage structure can be similar to those in countries with low adjustment costs and a high wage dispersion.

I use Swedish establishment data on job turnover and wages to test the Bertola and Rogerson hypothesis. The estimation technique is industry fixed-effects estimation on 14 two-digit industries. Results indicate large sector differences regarding the effect of the degree of wage dispersion on job reallocation. In accordance with Bertola and Rogerson, the effect is negative in the manufacturing sector. Furthermore, estimating separate regressions for job creation and job destruction yields a negative and significant effect of wage dispersion on job destruction and an insignificant effect on job creation. These results are in accordance with wages being more downward than upward rigid.

The quantitative effect of the impact of wage dispersion on job turnover is, however, relatively small. A one standard deviation increase in wage dispersion reduces the total job reallocation by around 10 percent. This means that for Sweden, the Bertola and Rogerson hypothesis can only explain a small part of the industryvariation in job reallocation. Turning to the non-manufacturing sector, the Bertola and Rogerson hypothesis is not supported.

Further results include (i) a very strong positive effect of the industry-share of temporary employees on job reallocation and (ii) a negative relationship between the use of overtime and job turnover. The latter result suggests that job reallocation is lower in industries where the number of hours worked is flexible. 
If the fraction of temporary employees is taken as a proxy for adjustment costs for labor, then the results indicate that the largest part of the variation in gross job flows is explained by differences in the cost of adjusting labor, rather than by differences in wage dispersion. As much as 25 percent of the variation in job flows is explained by variation in the industry-share of temporary employment. This result is in accordance with Arai and Heyman (2004), stressing the importance in distinguishing between permanent and temporary contracts when studying job flows.

\section{REFERENCES}

Abowd, John, Patrick Corbel and Francis Kramarz. "The Entry and Exit of Workers and the Growth of Employment: An Analysis of French Establishments.” Review of Economics and Statistics 81 (1999): 170-787.

Addison, John T. and Paulino Teixeira. "The Economics of Employment Protection." Journal of Labor Research 24 (2003): 85-129.

Agell, Jonas and Per Lundborg. "Survey Evidence on Wage Rigidity and Unemployment: Sweden in the 1990:s.” Scandinavian Journal of Economics 105 (2003): 15-30.

Albaek, Karsten and Bent E. Sörensen. "Worker Flows and Job Flows in Danish Manufacturing, 1980-1991.” Economic Journal 108 (1998): 1750-71.

Andersson, Fredrik. “Job Flows in Swedish Manufacturing 1972-96.” Working Paper 99:4, Office of Labour Market Policy Evaluation (IFAU), 1999.

Anderson, Patricia M. and Bruce D. Meyer. "The Extent and Consequences of Job Turnover.” Brookings Papers on Economic Activity; Microeconomics, 1994: 177-248.

Arai, Mahmood and Fredrik Heyman. "Temporary Contracts and the Dynamics of Job Turnover.” Economics Bulletin 10 (2004): 1-6.

Baltagi, B. (1995), Econometric Analysis of Panel Data. Chichester, UK: John Wiley \& Sons, 1995.

Bentolila, Samuel and Gilles Saint-Paul. "The Macroeconomic Impact of Flexible Labor Contracts, With an Application to Spain.” European Economic Review 36 (1992): 1013-1053.

Bertola, Giuseppe. "Job Security, Employment and Wages.” European Economic Review 34 (1990): 851-886.

Bertola, Giuseppe and Andrea Ichino, "Wage Inequality and Unemployment: U.S vs. Europe.” NBER Macroeconomic Annual, 1995.

Bertola, Giuseppe and Richard Rogerson. "Institutions and Labour Reallocation." European Economic Review 41 (1997): 1147-71.

Bewley, Truman F. "Why not cut pay?” European Economic Review 42 (1998): 459490.

Blanchard, Olivier and Augustin Landier. "The Perverse Effects of partial Labour market Reforms: Fixed-Term Contracts in France.” Economic Journal 112 (2002): 214-244. 
Blanchard, Olivier and Pedro Portugal. "What Hides Behind an Unemployment Rate: Comparing Portuguese and U.S. Labor Markets.” American Economic Review 91 (2001): 187-207.

Blau, Francine D. and Lawrence M. Kahn, "International Differences in Male Wage Inequality: Institutions versus Market Forces.” Journal of Political Economy 104 (1996): 791-837.

Boeri, Tito. ”Is Job Turnover Countercyclical?” Journal of Labor Economics 14 (1996): 603-25.

Davis, Steven J. and John Haltiwanger. "Gross Job Creation, Gross Job Destruction and Employment Reallocation.” Quarterly Journal of Economics 107 (1992): 819-63.

Davis, Steven J., John Haltiwanger and Scott Schuh. Job Creation and Destruction. Cambridge, MA: MIT Press, 1997.

Davis, Steven J. and John Haltiwanger. "Gross Job Flows.” In Orley C. Ashenfelter and David Card, eds. Handbook of Labor Economics. Amsterdam, The Netherlands: Elsevier Science B.V., 1999, pp. 2711-2803.

Dunne, Timothy. Mark Roberts and Larry Samuelson. "Plant Turnover and Gross Employment Flows in the U.S. Manufacturing Sector." Journal of Labour Economics 7 (1989): 48-71.

Edin, Per-Anders and Bertil Holmlund. "The Swedish Wage Structure: The Rise and Fall of Solidarity Wage Policy?” Working Paper No. 1992:13, Uppsala, Department of Economics, Uppsala University, 1992.

Hamermesh, Daniel, S., Wolter H.J. Hassinke and Jan C. Van Ours. ”Job Turnover and Labour Turnover: A Taxonomy of Employment Dynamics.” Annales d'Economie et de Statistique. 41/42 (1996): 21-40.

Heyman, Fredrik. "Wage Dispersion and Allocation of Jobs.” Working paper No. 479, Stockholm, Department of Economics, Stockholm School of Economics, 2002.

Hibbs, Douglas and Håkan Locking. "Wage Dispersion and Productive Efficiency: Evidence for Sweden.” Journal of Labor Economics 18 (2000): 755-782.

Holmlund, Bertil and Douglas Storrie. "Temporary Work in Turbulent Times: The Swedish Experience.” Economic Journal 112 (2002): 245-269.

Lane, Julia, David Stevens and Simon Burgess. "Worker and Job flows." Economics Letters 51 (1996): 109-13.

Leonard, Jonathan S. "In the Wrong Place at the Wrong Time: The extent of Frictional and Structural Unemployment.” In Kevin Lang and Jonathan S. Leonard, eds. Unemployment and the Structure of Labor Markets. Oxford: Basil Blackwell, 1987, pp. 141-163.

Moene Karl Ove and Michael Wallerstein. "Pay Inequality.” Journal of Labor Economics 15 (1997): 403-430

OECD (1993), Employment Outlook, Paris.

Persson Helena. Essays on Labor Demand and Career Mobility. PhD Dissertation. Swedish Institute for Social Research. Stockholm University, 1999.

Saint-Paul, Gilles. Dual Labour Markets: A Macroeconomic Perspective. Cambridge and London: MIT Press, 1996.

Wasmer, Etienne. "Competition for Jobs in a Growing Economy and the Emergence of Dualism.” Economic Journal 109 (1999): 349-371. 


\section{Appendix}

Table A1

Descriptive statistics. 14 industries, 1992:3-1999:2

\begin{tabular}{|c|c|c|c|c|c|c|c|c|c|c|}
\hline & $\begin{array}{c}\text { Real Wage } \\
\text { Blue-collar } \\
\text { workers }\end{array}$ & $\begin{array}{l}\text { Real Wage } \\
\text { White-collar } \\
\text { workers }\end{array}$ & $\begin{array}{c}\text { CV } \\
\text { Blue-collar } \\
\text { Workers }\end{array}$ & $\begin{array}{c}\text { CV } \\
\text { White-collar } \\
\text { Workers }\end{array}$ & $\begin{array}{c}\text { CV } \\
\text { All } \\
\text { Workers }\end{array}$ & $\begin{array}{c}\mathrm{p}(90 / 10) \\
\text { Blue-collar } \\
\text { Workers }\end{array}$ & $\begin{array}{c}\mathrm{p}(90 / 10) \\
\text { White-collar } \\
\text { Workers }\end{array}$ & $\begin{array}{c}\mathrm{p}(90 / 10) \\
\text { All } \\
\text { workers }\end{array}$ & $\begin{array}{l}\text { Fraction } \\
\text { overtime }\end{array}$ & $\begin{array}{c}\text { Fraction } \\
\text { Temporary } \\
\text { Employees }\end{array}$ \\
\hline \multirow[t]{2}{*}{ Banking: } & 74.75 & 19954 & 0.15 & 0.23 & 0.23 & 1.44 & 1.64 & 1,64 & 0.03 & 0.07 \\
\hline & 5.24 & 1463 & 0.03 & 0.02 & 0.02 & 0.08 & 0.09 & 0,09 & 0.01 & 0.02 \\
\hline \multirow[t]{2}{*}{ Construct.: } & 92.80 & 19087 & 0.11 & 0.16 & 0.13 & 1.28 & 1.46 & 1,34 & 0.02 & 0.11 \\
\hline & 4.31 & 894 & 0.01 & 0.01 & 0.01 & 0.03 & 0.03 & 0,02 & 0.00 & 0.03 \\
\hline Electr. Etc.:Mean & 92.23 & 18189 & 0.11 & 0.12 & 0.12 & 1.28 & 1.30 & 1,29 & 0.04 & 0.04 \\
\hline STD & 5.98 & 1141 & 0.02 & 0.02 & 0.02 & 0.05 & 0.03 & 0,03 & 0.01 & 0.02 \\
\hline Real Estate:Mean & 79.41 & 18072 & 0.12 & 0.19 & 0.16 & 1.33 & 1.42 & 1,38 & 0.02 & 0.12 \\
\hline STD & 5.35 & 876 & 0.02 & 0.02 & 0.01 & 0.05 & 0.06 & 0,04 & 0.00 & 0.02 \\
\hline \multirow[t]{2}{*}{ Food: } & 85.21 & 18276 & 0.11 & 0.17 & 0.13 & 1.32 & 1.39 & 1,35 & 0.03 & 0.15 \\
\hline & 5.17 & 1502 & 0.01 & 0.03 & 0.01 & 0.04 & 0.05 & 0,04 & 0.00 & 0.03 \\
\hline Hotel-Res.:Mean & 72.21 & 16787 & 0.13 & 0.15 & 0.13 & 1.36 & 1.39 & 1,37 & 0.01 & 0.28 \\
\hline STD & 3.23 & 915 & 0.02 & 0.03 & 0.02 & 0.06 & 0.06 & 0,05 & 0.01 & 0.04 \\
\hline Chemistry: Mean & 90.74 & 20099 & 0.13 & 0.14 & 0.14 & 1.37 & 1.38 & 1,38 & 0.04 & 0.06 \\
\hline STD & 6.41 & 1633 & 0.01 & 0.01 & 0.01 & 0.03 & 0.05 & 0,04 & 0.00 & 0.01 \\
\hline Machinery:Mean & 88.80 & 19537 & 0.12 & 0.16 & 0.13 & 1.32 & 1.37 & 1,35 & 0.04 & 0.05 \\
\hline STD & 5.94 & 1457 & 0.01 & 0.01 & 0.01 & 0.03 & 0.05 & 0,04 & 0.01 & 0.01 \\
\hline \multirow[t]{2}{*}{ Mining: } & 106.34 & 19301 & 0.13 & 0.13 & 0.13 & 1.37 & 1.40 & 1,38 & 0.06 & 0.08 \\
\hline & 7.61 & 1480 & 0.01 & 0.03 & 0.01 & 0.04 & 0.07 & 0,04 & 0.01 & 0.04 \\
\hline Oth. Serv.: Mean & 80.67 & 17990 & 0.18 & 0.22 & 0.22 & 1.50 & 1.71 & 1,68 & 0.02 & 0.14 \\
\hline STD & 4.25 & 1156 & 0.02 & 0.01 & 0.01 & 0.03 & 0.04 & 0,04 & 0.00 & 0.01 \\
\hline \multirow[t]{2}{*}{ Textile: } & 76.61 & 17483 & 0.12 & 0.16 & 0.13 & 1.30 & 1.48 & 1,35 & 0.02 & 0.04 \\
\hline & 4.85 & 953 & 0.01 & 0.01 & 0.01 & 0.03 & 0.06 & 0,02 & 0.00 & 0.01 \\
\hline \multirow[t]{2}{*}{ Trade: } & 80.08 & 17820 & 0.13 & 0.20 & 0.17 & 1.33 & 1.55 & 1,46 & 0.02 & 0.12 \\
\hline & 5.23 & 1133 & 0.01 & 0.01 & 0.01 & 0.02 & 0.03 & 0,03 & 0.00 & 0.01 \\
\hline \multirow[t]{2}{*}{ Transport: } & 87.86 & 16718 & 0.16 & 0.19 & 0.17 & 1.37 & 1.47 & 1,42 & 0.04 & 0.12 \\
\hline & 5.98 & 1384 & 0.02 & 0.02 & 0.01 & 0.03 & 0.04 & 0,03 & 0.01 & 0.02 \\
\hline \multirow[t]{2}{*}{ Wood etc.: } & 96.14 & 18413 & 0.17 & 0.18 & 0.17 & 1.49 & 1.42 & 1,46 & 0.04 & 0.06 \\
\hline & 6.82 & 1533 & 0.01 & 0.02 & 0.01 & 0.05 & 0.07 & 0,05 & 0.00 & 0.01 \\
\hline \multirow[t]{2}{*}{ Manufact.: } & 90.64 & 18851 & 0.13 & 0.15 & 0.14 & 1.36 & 1.41 & 1.38 & 0.04 & 0.07 \\
\hline & 11.06 & 1672 & 0.02 & 0.03 & 0.02 & 0.07 & 0.07 & 0.06 & 0.01 & 0.04 \\
\hline Non-manu.:Mean & 82.50 & 18077 & 0.14 & 0.18 & 0.17 & 1.36 & 1.49 & 1.45 & 0.03 & 0.12 \\
\hline STD & 8.75 & 1510 & 0.03 & 0.04 & 0.04 & 0.08 & 0.14 & 0.14 & 0.01 & 0.07 \\
\hline
\end{tabular}

Table A2

Descriptive statistics. Quarterly gross job flow rates, 1992:3-1999:2

\begin{tabular}{llcccc}
\hline & & Job & Job & Job \\
Creation & Destruction & $\begin{array}{c}\text { Net Empl. } \\
\text { Reallocation } \\
\text { Change }\end{array}$ \\
\hline Private sector & Mean & 0.04 & 0.04 & 0.08 & -0.01 \\
& STD & 0.02 & 0.03 & 0.04 & 0.01 \\
\hline Manufacturing & Mean & 0.03 & 0.03 & 0.06 & -0.01 \\
& STD & 0.02 & 0.02 & 0.02 & 0.01 \\
\hline Non-manufacturing & Mean & 0.05 & 0.05 & 0.10 & 0.00 \\
& STD & 0.03 & 0.03 & 0.04 & 0.01 \\
\hline
\end{tabular}


Table 1

Effects of wage dispersion, fraction temporary employees, and use of overtime on job reallocation. Industry fixed-effects regressions. Dependent variable is job reallocation rate (JRR). Robust standard errors in parenthesis.

\begin{tabular}{|c|c|c|c|c|c|c|}
\hline & 1 & 2 & 3 & 4 & 5 & 6 \\
\hline & \multicolumn{6}{|c|}{ Job reallocation rate $(J R R)$} \\
\hline Wage dispersion & $\begin{array}{l}0.09 \\
(0.09)\end{array}$ & $\begin{array}{l}-0.33^{* * *} \\
(0.11)\end{array}$ & $\begin{array}{l}0.26 * * \\
(0.12)\end{array}$ & $\begin{array}{l}0.02 \\
(0.03)\end{array}$ & $\begin{array}{l}-0.09 * * * \\
(0.03)\end{array}$ & $\begin{array}{l}0.09 * * \\
(0.04)\end{array}$ \\
\hline Fraction temp. employees & $\begin{array}{l}0.30 * * * \\
(0.06)\end{array}$ & $\begin{array}{l}0.38^{* * *} \\
(0.0)\end{array}$ & $\begin{array}{l}0.25^{* * *} \\
(0.09)\end{array}$ & $\begin{array}{l}0.30 * * * \\
(0.06)\end{array}$ & $\begin{array}{l}0.38 * * * \\
(0.06)\end{array}$ & $\begin{array}{l}0.22^{* *} \\
(0.10)\end{array}$ \\
\hline Overtime & $\begin{array}{l}-0.56^{*} \\
(0.16)\end{array}$ & $\begin{array}{l}-0.56^{* * *} \\
(0.32)\end{array}$ & $\begin{array}{l}-0.54^{*} \\
(0.21)\end{array}$ & $\begin{array}{l}-0.55^{* * *} \\
(0.16)\end{array}$ & $\begin{array}{l}-0.62^{* * *} \\
(0.32)\end{array}$ & $\begin{array}{l}-0.53^{* * *} \\
(0.21)\end{array}$ \\
\hline Net employment change & $\begin{array}{l}-0.15^{* *} \\
(0.07)\end{array}$ & $\begin{array}{l}-0.15^{*} \\
(0.10)\end{array}$ & $\begin{array}{l}-0.11 \\
(0.11)\end{array}$ & $\begin{array}{l}-0.16^{* *} \\
(0.08)\end{array}$ & $\begin{array}{l}-0.16^{*} \\
(0.10)\end{array}$ & $\begin{array}{l}-0.16 \\
(0.11)\end{array}$ \\
\hline Industry & All & Manuf. & $\begin{array}{l}\text { Non } \\
\text { manuf. }\end{array}$ & All & Manuf. & $\begin{array}{l}\text { Non } \\
\text { manuf. }\end{array}$ \\
\hline Measure of wage dispersion & $\mathrm{CV}$ & $\mathrm{CV}$ & $\mathrm{CV}$ & $\mathrm{p}(90 / 10)$ & $\mathrm{p}(90 / 10)$ & $\mathrm{p}(90 / 10)$ \\
\hline Hausman test & 4.54 & $7.6^{*}$ & $14.3^{* * *}$ & 6.7 & $8.0^{*}$ & $12.8^{*}$ \\
\hline Breusch and Pagan test & $459 * * *$ & 1.5 & $67.4 * * *$ & $466 * * *$ & 1.8 & $94 * * *$ \\
\hline $\mathrm{R}^{2}$ & 0.78 & 0.52 & 0.52 & 0.78 & 0.51 & 0.76 \\
\hline $\mathrm{N}$ & 392 & 168 & 168 & 392 & 168 & 224 \\
\hline $\mathrm{T}$ & 28 & 28 & 28 & 28 & 28 & 28 \\
\hline
\end{tabular}

Notes:

(i) * indicate significance at the $10 \%$-level, ** at the $5 \%$-level and *** at the $1 \%$-level.

(ii) Industry classification corresponds to 14 industries (6 in manufacturing and 8 in non manufacturing).

(iii) $\mathrm{CV}=$ coefficient of variation. $\mathrm{p}(90 / 10)=90$-10th percentile ratio.

(iv) The Breusch and Pagan LM-test is a test for individual (industry) random effects. The null-hypothesis is that the variance in the industry-specific effects is equal to zero. Rejection of the null shows that industry-specific effects are present. 
Table 2

Effects of wage dispersion, fraction temporary employees and use of overtime on job flows. Industry fixed-effects regressions. Dependent variables are job creation rate (JCR) and job destruction rate (JDR). Robust standard errors in parenthesis.

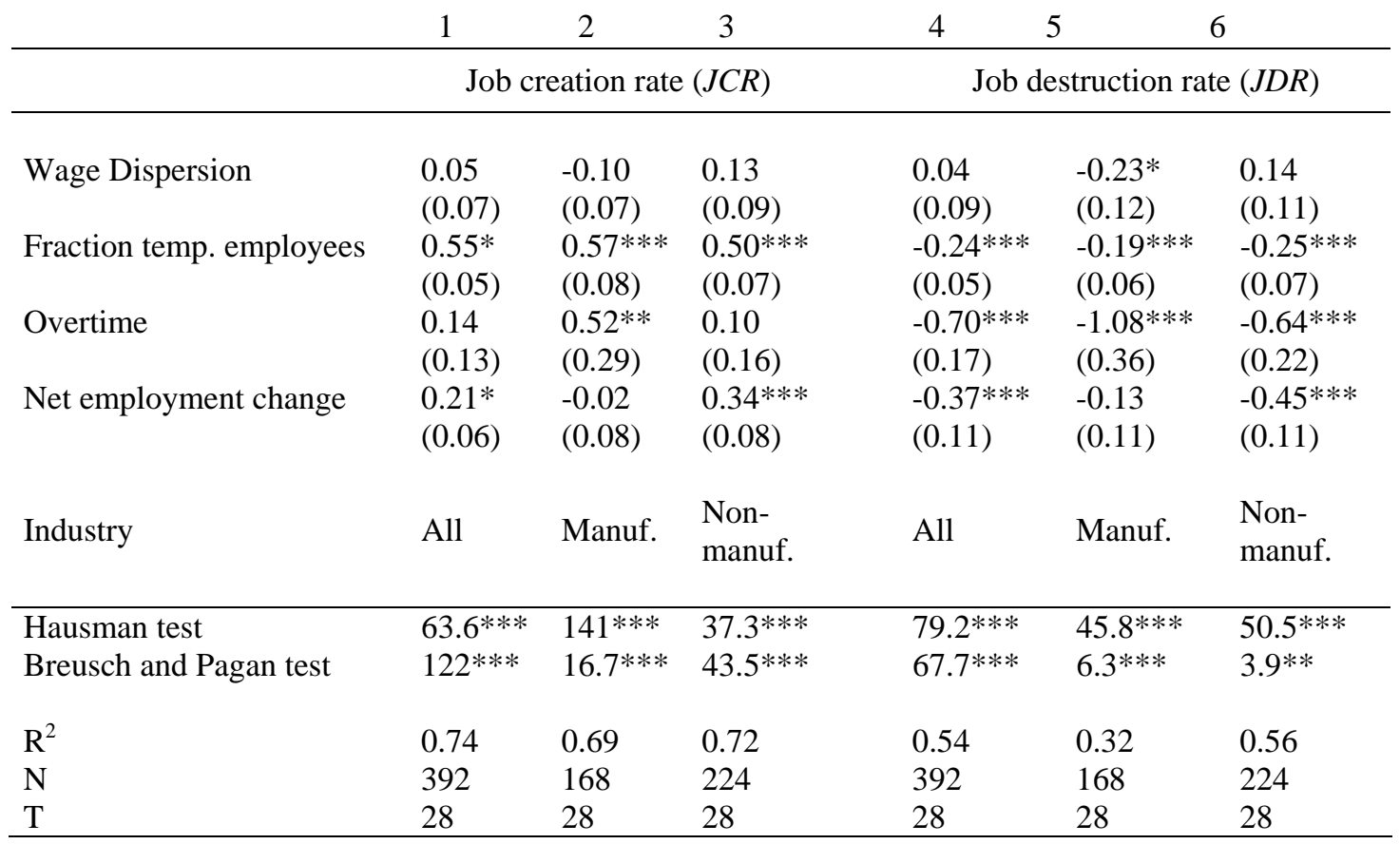

Notes:

(i) * indicate significance at the $10 \%$-level, ** at the $5 \%$-level and *** at the $1 \%$-level.

(ii) $\mathrm{CV}=$ coefficient of variation is used as a measure for wage dispersion. Results remain qualitatively unchanged when $\mathrm{p}(90 / 10)$ is used as a measure for wage dispersion.

(iii) Industry classification corresponds to 14 industries (6 in manufacturing and 8 in non-manufacturing).

(iv) The Breusch and Pagan LM-test is a test for individual (industry) random effects. The null-hypothesis is that the variance in the industry-specific effects is equal to zero. Rejection of the null shows that industryspecific effects are present. 
Table 3

Effects of wage dispersion, fraction temporary employees and use of overtime on job flows. Industry fixed-effects regressions using IV-analysis. Dependent variables are job creation rate (JCR) and job destruction rate (JDR). Robust standard errors in parenthesis.

\begin{tabular}{|c|c|c|c|}
\hline & 1 & 2 & 3 \\
\hline & $J R R$ & $J C R$ & $J D R$ \\
\hline Wage Dispersion & $\begin{array}{l}-0.57 * * \\
(0.26)\end{array}$ & $\begin{array}{l}-0.09 \\
(0.18)\end{array}$ & $\begin{array}{l}-0.48 * \\
(0.29)\end{array}$ \\
\hline Fraction temp. employees & $\begin{array}{l}0.40 * * * \\
(0.07)\end{array}$ & $\begin{array}{l}0.63 * * * \\
(0.09)\end{array}$ & $\begin{array}{l}-0.23^{* * *} \\
(0.07)\end{array}$ \\
\hline Overtime & $\begin{array}{l}-0.82^{*} \\
(0.42)\end{array}$ & $\begin{array}{l}0.74 * * * \\
(0.29)\end{array}$ & $\begin{array}{l}-1.56^{* * *} \\
(0.47)\end{array}$ \\
\hline Net employment change & $\begin{array}{l}-0.18 \\
(0.14)\end{array}$ & $\begin{array}{l}0.10 \\
(0.10)\end{array}$ & $\begin{array}{l}-0.28^{* *} \\
(0.14)\end{array}$ \\
\hline Industry & Manuf. & Manuf. & Manuf. \\
\hline Wu-Hausman F-test & 0.96 & 2.09 & 0.00 \\
\hline $\mathrm{R}^{2}$ & 0.51 & 0.72 & 0.34 \\
\hline $\mathrm{N}$ & 144 & 144 & 144 \\
\hline $\mathrm{T}$ & 24 & 24 & 24 \\
\hline Ist step estimates & $\begin{array}{l}0.53 * * * \\
(0.07)\end{array}$ & $\begin{array}{l}0.53 * * * \\
(0.07)\end{array}$ & $\begin{array}{l}0.53 * * * \\
(0.07)\end{array}$ \\
\hline
\end{tabular}

Notes:

(i) * indicate significance at the $10 \%$-level, ** at the 5\%-level and *** at the $1 \%$-level.

(ii) $\mathrm{CV}=$ coefficient of variation is used as a measure for wage dispersion. Results remain qualitatively unchanged when $\mathrm{p}(90 / 10)$ is used as a measure for wage dispersion.

(iii) Industry classification corresponds to 14 industries (6 in manufacturing and 8 in non-manufacturing).

(iv) The Wu-Hausman F-test is a test if there is a systematic difference between the OLS- and the IVestimator. The null-hypothesis is that the wage dispersion variable is exogenous. 